\title{
The Relations Teacher Profession Interest and Teacher Attitudes with Readiness Teaching Students Study Program Office Administration of Education Faculty of Economics Yogyakarta State University
}

\author{
Fitri Handayani Setiyadi, Cepi Safruddin Abdul Jabar, Siti Umi Khayatun Mardiyah \\ \{fhsetiyadi6492@gmail.com ${ }^{1}$, cepi_saffrudin@uny.ac.id², umikha@uny.ac.id ${ }^{3}$ \}
}

\begin{abstract}
Educational Management, Postgraduate Program, Yogyakarta State University, Jl.Colombo No.1, Karangmalang, Caturtunggal, Depok, Sleman, Special Region of Yogyakarta 55281, Indonesia ${ }^{1,2}$ Faculty of Economics, Yogyakarta State University, Jl.Colombo No.1, Karangmalang, Caturtunggal, Depok, Sleman, Special Region of Yogyakarta 55281, Indonesia ${ }^{3}$
\end{abstract}

\begin{abstract}
The aim of this research is to understand 1) the relation teacher profession interest and readiness teaching students, 2) the relation teacher attitudes and readiness teaching students, and 3 ) the relations teacher profession interest and teacher attitudes with readiness teaching students. This research methods using ex-post facto and quantitative approach. The population was all as research subjects totaling 90 students of the study program Office Administration of Education Faculty of Economics Yogyakarta State University class of 2012 (class A as many as 67 and class B as many as 33). A questionnaire (instruments with the help of closed questionnaire guidelines) and documentation are the data collection used in this research. Meanwhile, this research data analysis technique is interactive analysis with three steps as follows validity test, prerequisite test, and hypothesis testing. The results of this research show that (1) there is a positive and significant relations teacher profession interest with readiness teaching is shown by the calculated value of correlation coefficient of 0.638 and significance value $0.000<0.05$, which means a significant; (2) there is a positive and significant relations teacher attitudes with readiness teaching is shown by the calculated value of correlation coefficient of 0.354 and significant value of $0.000<0.05$, which means a significant; and (3) there is a positive and significant relations teacher profession interest and teacher attitudes with readiness teaching is shown by the calculated value of coefficient determination (R2) of 0.428 and significance value $0.000<0.05$, which means a significant with the useful/effective contribution of $42.79 \%$.
\end{abstract}

Keywords: teacher profession interest, teacher attitudes, readiness teaching.

\section{Introduction}

Education is an effort to educate the Nation's life. According to law UU No.20 of 2003 concerning the National Education System (Sisdiknas), education is a conscious and planned effort to create an atmosphere of learning and the learning process so that students actively develop their potential to have religious, spiritual strength, self-control, personality, 
intelligence, noble character, and abilities, which is needed by himself, society, nation, and state. Education is a process of producing quality human resources.

The world of education cannot be separated from the figure of a teacher. The teacher is the most decisive component in education. Teachers play a significant role in education development, especially those held formally in schools. The teacher also determines the level of success of each student. The teacher is one component of the education sector that plays an active role in increasing adequate knowledge and skills in teacher training following the demands of the times, advances in science and technology. Teachers are the spearhead of the quality of education based on the quality of the teaching and learning process (PBM). The teacher's function is as an educator, tutor, mentor, trainer, program developer, program manager, and professional staff. Professional teachers must possess teacher duties and functions that describe competencies. Teachers are role models for students, but education/teach students still do not fully have a personality that shows a professional teacher attitude. Students have already received Teaching Professional Ethics courses, but student attitudes still do not reflect a teacher's personality.

Efforts (teacher profession interest) to prepare (teacher attitudes, and readiness teaching students) an educational student are not easy. Students are often late for college, skip the class session, and late submitting assignments. Students bad habits, such as being lazy to read books, underestimate, or ignore the assignments. Students still often copy and paste material from the internet and commit dishonest acts such as plagiarism or plagiarizing friends assignments. Some educational students who do not want to become teachers after graduated and choose to work in office are lazy and tired of preparing complicated teacher administration.

Teaching does not only convey knowledge but values that are used as provisions to instill a religious spirit, independence and responsibility for students. The improvement of teacher skills in preparing and managing the Teaching and Learning Process (PBM) needs to be pursued and prepared for maturity. Based the background of the study, we interested to research The Relations Teacher Profession Interest and Teacher Attitudes with Readiness Teaching Students Study Program Office Administration of Education Faculty of Economics Yogyakarta State University.

\section{Methods}

The type of study is ex-post facto research because in this study, there was no special treatment or manipulation of the studied variables. The approach used is quantitative. The quantitative approach is used to measure independent and dependent variables using the numbers obtained through statistical analysis (SPSS). This approach is used to test the hypothesis used. For this reason, this study looks for connection the independent variables and dependent variable.

This study population was all students of the Office Administration Education Study Program class of 2012, totaling 90 people (class A as many as 67 and class B as many as 33), all as research subjects. The data was obtained from the information from the Head of the Department of study program Office Administration of Education Faculty of Economics Yogyakarta State University, the website, and the Department Admin, which will be used to obtain students profile data and total of students data class of the 2012. A questionnaire and documentation are the data collection used in this research. This study used research instruments with the help of closed questionnaire guidelines and documentation. This research data analysis technique is interactive analysis with three steps as follows 1) validity test;2) analysis prerequisite test; and 3) hypothesis testing. 


\section{Result and Discussion}

Teacher profession interest variable data was obtained by filling out a questionnaire consisting of 16 statement items. Based on the calculations, the data is presented with a pie chart, which can be seen in Figure 1 as follows.

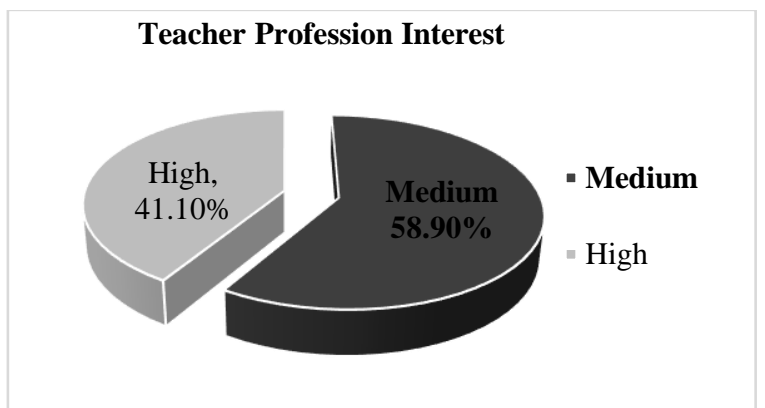

Fig. 1. Pie Chart of Frequency Distribution of Teacher Profession Interest Students Study Program Office Administration of Education Faculty of Economics Yogyakarta State University.

Based on Figure 1, it can be seen that the frequency distribution of teacher profession interest is in the medium category with a percentage of $58.9 \%$. Which mean that not all respondent have a high interest in the teaching profession.

Teacher attitudes variable data obtained by filling out a questionnaire consisting of 10 statement items. Based on the calculation, the data is presented with a pie chart, which can be seen in Figure 2 as follows.

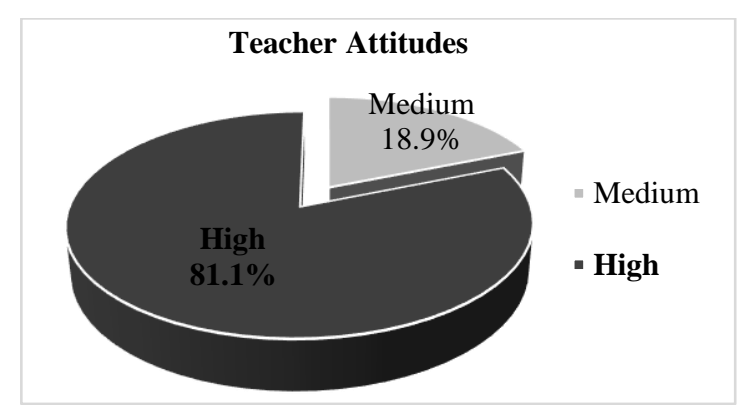

Fig. 2. Pie Chart of Frequency Distribution of Teacher Attitudes Students Study Program Office Administration of Education Faculty of Economics Yogyakarta State University.

Based on Figure 2, it can be seen that the frequency distribution of teacher attitudes is in the high category with a percentage of $81.1 \%$. Which mean that most respondents have a high teacher attitude. Readiness Teaching variable data was obtained by filling out a questionnaire consisting of 15 statement items. Based on the calculations, the data is presented with a pie chart, which can be seen in Figure 3 as follows. 


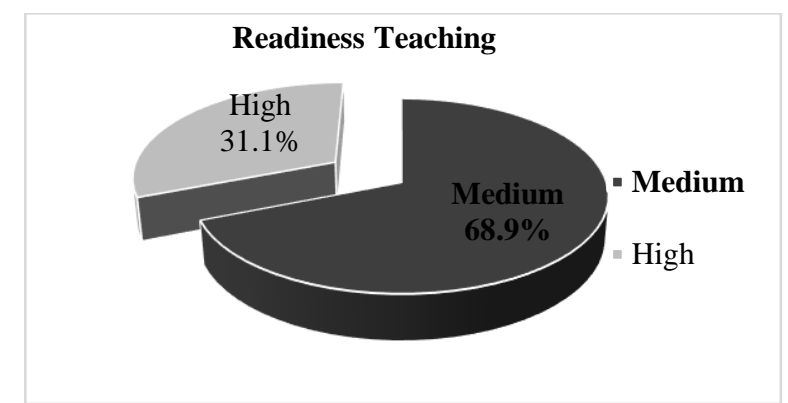

Fig. 3. Pie Chart of Frequency Distribution of Readiness Teaching Students Study Program Office Administration of Education Faculty of Economics Yogyakarta State University.

Based on Figure 3, it can be seen that the frequency distribution of the teacher profession interest is in the medium category with a percentage of $68.9 \%$. Which mean that not all respondents have high readiness teaching. The summary of the analysis results can be seen in the following tables.

Table 1. The Results of Correlation Teacher Profession Interest $\left(\mathrm{X}_{1}\right)$ and Readiness Teaching $(\mathrm{Y})$.

\begin{tabular}{|c|c|c|c|c|}
\hline Variables & \multicolumn{2}{|c|}{ Cost $\mathbf{r}$} & \multirow{2}{*}{ Sig. } & Description \\
\cline { 2 - 3 } & Count & Table & & $\begin{array}{c}\text { Positive } \\
\text { and } \\
\text { Significant }\end{array}$ \\
\hline Teacher Profession Interest $\left(\mathbf{X}_{1}\right)$ & 0,638 & 0,207 & 0,000 & \\
Readiness Teaching $\left(\mathbf{X}_{2}\right)$ & & & &
\end{tabular}

Source: Primary data that has been processed.

Based on the Table 1, the correlation coefficient $\left(\mathrm{rX}_{1} \mathrm{Y}\right)$ shows that the correlation of the Teacher Profession Interest variable $\left(\mathrm{X}_{1}\right)$ with Readiness Teaching $(\mathrm{Y})$ is 0.638 . These results indicate that $r_{\text {count }}(0.638)>r_{\text {table }}(0.207)$ and a significance value of 0.000 , which means less than $0.05(0.000<0.05)$, so it can be concluded that the relations teacher profession interest and readiness teaching is significant.

Table 2. The Results of Correlation of Teacher Attitudes (X2) and Teaching Readiness (Y).

\begin{tabular}{|c|c|c|c|c|}
\hline \multirow{2}{*}{ Variables } & \multicolumn{2}{|c|}{ Cost $r$} & \multirow{2}{*}{ Sig. } & \multirow{2}{*}{ Description } \\
\hline & Count & Table & & \\
\hline $\begin{array}{l}\text { Teacher Attitudes }\left(\mathrm{X}_{2}\right) \\
\text { Readiness Teaching }(\mathrm{Y})\end{array}$ & 0,354 & 0,207 & 0,000 & $\begin{array}{c}\text { Positive } \\
\text { and } \\
\text { Significant }\end{array}$ \\
\hline
\end{tabular}

Source: Primary data that has been processed.

Based on the Table 2, the correlation coefficient (rx1y) shows that the correlation of the Teacher Attitude (X2) variable with Teaching Readiness (Y) is 0.354 . These results indicate that $r_{\text {count }}(0.354)>r_{\text {table }}(0.207)$ and a significance value of 0.000 , which means less than 0,05 $(0.000<0.05)$, so it can be concluded that the relations teacher attitudes and readiness teaching is significant.

Table 3. Multiple Correlation Results.

\begin{tabular}{|c|c|c|c|c|}
\hline $\mathbf{r}_{\text {count }}$ & $\mathbf{r}_{\text {table }}$ & Sig & $\mathbf{R}^{\mathbf{2}}$ & $\mathbf{F}$ \\
\hline 0,665 & 0,207 & 0,000 & 0,428 & 32,604 \\
\hline
\end{tabular}

Source: Primary data that has been processed. 
Based on the Table 3, it can be seen that there is a positive relations the Teacher Profession Interest and Teacher Attitudes with Readiness Teaching Students. The result of $r_{\text {count }}$ of 0.655 greater than stable $(0.655>0.207)$ and a significance value of 0.000 which means less from $0.05(0.000<0.05)$. The significance test aims to determine the significance of the correlation Teacher Profession Interest $\left(\mathrm{X}_{1}\right)$ and Teacher Attitude $\left(\mathrm{X}_{2}\right)$ with Readiness Teaching Student (Y). The significance test used Fest. Based on the test results obtained the F value of 32.604. When compared with the Ftable value of 3.10 at the $5 \%$ significance level, then the $\mathrm{F}_{\text {count }}$ value> $\mathrm{F}_{\text {table }}$ so that the third hypothesis is accepted. The Coefficient of Determination $\left(\mathrm{R}^{2}\right)$ is 0.428 or $42.8 \%$. These results indicate that teaching readiness can be explained by the variables of teacher profession interest and teacher attitudes by $42.8 \%$, while the remaining $57.2 \%$ is explained by other variables not examined. Relative Contribution (RC) and Effective Contribution (EC) of each independent variable (Teacher Profession Interest and Teacher Attitudes variables) to the dependent variable (Readiness Teaching variable). The magnitude of RC and EC can be seen in Table 4.

Table 4. Contribution Weights of Each Independent Variable.

\begin{tabular}{|c|c|c|}
\hline Variables & $\begin{array}{c}\text { Effective } \\
(\boldsymbol{\%})\end{array}$ & Relative $(\boldsymbol{\%})$ \\
\hline Teacher Proffesion Interest $\left(\mathbf{X}_{\mathbf{1}}\right)$ & 31,22 & 72,95 \\
\hline Teacher Attitudes $\left(\mathbf{X}_{\mathbf{2}}\right)$ & 11,57 & 27,05 \\
\hline Total & $\mathbf{4 2 , 7 9}$ & $\mathbf{1 0 0 , 0 0}$ \\
\hline
\end{tabular}

Source: Primary data that has been processed.

Based on the results of the analysis listed in the Table 4, it can be seen that the Teacher Profession Interest provides a Relative Contribution of $72.95 \%$, the Teacher Attitude provides a Relative Contribution of $27.05 \%$. Simultaneously, the Effective Contribution of each variable is the Profession Interest of the Teacher of $31,22 \%$, and teacher attitudes of $11.57 \%$. The total useful contribution is 42.79 , which means that together the variables of Teacher Profession Interest and Teacher Attitude provide an Effective Contribution of $42.79 \%$ with Teaching Readiness. In comparison, $57.21 \%$ is given by other variables that are not discussed in this study.

\subsection{The Relations Teacher Profession Interest and Readiness Teaching Students Study Program Office Administration of Education Faculty of Economics Yogyakarta State University}

The results of this research, indicate a positive and significant relations Teacher Profession Interest and Readiness Teaching Students Study Program Office Administration of Education Faculty of Economics Yogyakarta State University Class 2012 by the Correlation Coefficient (r) of 0.638. Based on the correlation analysis results that have been carried out in this study using Product Moment Correlation Analysis from Karl Pearson, the $r_{\text {count }}$ value is greater than the $r_{\text {table }}(0.638>0.207)$. In contrast, the significance value shows the result of 0.000 , which means less than $0.05(0.000<0,05)$, so it can be concluded that the relations Teacher Profession Interest and Readiness Teaching Students Study Program Office Administration of Education Faculty of Economics Yogyakarta State University is significant, so from these calculations it is found that there is a positive and significant relations teacher profession interest and readiness teaching students.

Teacher Profession Interest is one of the factors related to Readiness Teaching Student. This result follows Andi Mappiare (2012, p.62) who states that "interest is a mental device consisting of a mixture of feelings, expectations, convictions, prejudices or tendencies that lead 
individuals to a certain choice."[2] The choice referred to in this case, is the choice of the teacher profession. Teacher profession interest can arise because of information about the teacher profession, followed by feelings of pleasure and interest in the teacher profession. Furthermore, he/she will pay great attention and raise a feeling of interest in understanding and learning about the teacher profession.

\subsection{The Relations Teacher Attitudes and Readiness Teaching Students Study Program Office Administration of Education Faculty of Economics Yogyakarta State University}

The results of this research, indicate that there is a positive and significant relations Teacher Attitudes and Readiness Teaching Students Study Program Class of 2012, which is indicated by a Correlation Coefficient ( $r$ ) of 0.354. Based on the correlation analysis results that have been carried out in this study using the Product Moment Correlation Analysis from Karl Pearson, the $r_{\text {count }}$ value is greater than the $r_{\text {table }}(0.354>0.207)$. In contrast, the significance value shows a result of 0.000 , which means less than $0.05(0.000<0,05)$, so it can be concluded that the relations between teacher attitudes and teaching readiness is significant, so from these calculations, it is found that there is a positive and significant relations teacher attitudes and readiness teaching students.

This result is following the opinion of Bimo Walgito (2013, p.16), who states that "attitudes contain a feeling factor and motivation," which means that the attitude that a person takes towards a particular object will always be followed by certain feelings as well, this can be positive but can also be hostile towards that object.[3] Besides, attitudes also contain motivation, and this means that these attitudes have a strong impetus for individuals to behave in a certain way towards the objects they face. What must be done to foster positive feelings and motivation in developing behavior towards an object, in this case, is that behavior as a prospective teacher needs to be equipped with various teacher sciences as a basis, accompanied by a set of teacher skills training and in that condition learning to personalize some of the required attitudes. A positive and significant correlation of $r_{x y}$ of 0.354 teacher attitudes and readiness teaching students in this research supports the opinion stated above. Therefore, this study proves that the second hypothesis states that there is a positive and significant relations Teacher Attitudes and Readiness Teaching Students Study Program Office Administration of Education Faculty of Economics Yogyakarta State University.

\subsection{The Relations Teacher Profession Interest and Teacher Attitudes with Readiness Teaching Students Study Program Office Administration of Education Faculty of Economics Yogyakarta State University}

The research results were conducted jointly between the two independent variables and the dependent variable, and there is a positive and significant relations Teacher Profession Interest and Teacher Attitudes with Readiness Teaching Students Study Program Office Administration of Education Faculty of Economics Yogyakarta State University. The results of statistical testing using the Product Moment Correlation Analysis from Karl Pearson obtained a $\mathrm{r}_{\text {count }}$ value of 0.655 , which is greater than stable $(0.655>0.207)$, and the significance value is 0.000 less than $0.05(0.000<0.05)$.

Based on the results of the Multiple correlation analysis in this study, the coefficient of determination shows that the Teaching Readiness variable can be explained by the combination of the two independent variables, namely R2 of 0.428 , which means $42.8 \%$ of the Teaching Readiness variable can be influenced by the Profession Interest of Teachers and Teacher 
Attitudes. In contrast, the remaining 57.2\% is influenced by other variables not examined in this study. The calculation of the Relative Contribution of the Teacher Profession Interest variable $\left(X_{1}\right)$ is $72.95 \%$, and the Teacher Attitude variable $\left(X_{2}\right)$ is $27.05 \%$, while the Effective Contribution of each independent variable is $42.79 \%$ consisting of the Teacher Profession Interest variable $\left(X_{1}\right) 31.22 \%$ and the Teacher Attitude variable $\left(X_{2}\right) 11.57 \%$.

This multiple correlation analysis result follows the opinion of Slameto $(2012$, p.59) which states that "readiness is willingness to respond or react. Willingness arises in a person and maturity because means readiness to carry out skills."[10] A person is said to be ready to do a job, and if there is maturity in him to carry out skills, in other words, teaching readiness means a condition or state that is ready or capable so that readiness is defined as a physical and mental development that is perfect or ready to use. So a prospective teaching staff must have the readiness to teach to become a professional educator. Ready in terms of physical, mental, and attitude, which is influenced by the teacher profession interests and the teacher attitudes the prospective educators have. Increasing students teaching readiness cannot be separated from the efforts and cooperation between lecturers and students. There is encouragement from within students to continue to explore their abilities and desire to become professional educators; students willingness to learn will increase teaching readiness.

\section{Conclusion}

Based on the results of this research can be concluded, the contribution of research results to the scientific field, this research provides information that relations the teacher professional interest and teacher attitudes with readiness teaching students has an effective contribution of $42.79 \%$, but there is still a relations equal to $57.21 \%$ from other factors not examined in this study, so it is hoped that further research can use other variables or add variables that have a relations with readiness to teach. Possible give some suggestions as follows teacher profession interest read articles about the teaching profession covering types teacher work, teacher assignments, and matters related to teacher's job, teacher attitudes to seek information about attitudes good teacher like how to dress neatly, show high discipline things that are related to teacher attitudes, and teaching readiness prepare all kinds of things about teaching readiness such as the preparation of lesson plans, syllabus, teaching materials, and media learning. The recommendation of this research can be expected to be input for students that fosters interest in the teaching profession and developing teacher attitudes something that is absolutely necessary for a prospective teacher, in particular in developing the potential for teaching abilities as efforts to improve teaching readiness. Someone being a teacher is a noble job, even though it is a teacher's job full of responsibility, but very useful for Country.

Acknowledgements. We thank all parties for prayer, help, encouragement, motivation so that it is resolved properly and hopefully it is useful for readers.

\section{References}

[1] Altay Eren. Prospective Teachers' Interest in Teaching, Professional Plans about Teaching and Career Choice Satisfaction: a Relevant Framework?. 2012; https://doi.org/10.1177/000494411205600308. Volume: 56 issue: 3, page(s): 303-318.

[2] Andi Mappiare. Psikologi Remaja. Surabaya: Usaha Nasional; 2012.

[3] Bimo Walgito. Pengantar Psikologi Umum. Yogyakarta: ANDI Yogyakarta; 2013. 
[4] Ening Widihastuti. Pelaksanaan Keterampilan Mengajar Mahasiswa Program Studi Pendidikan Administrasi Perkantoran Fakultas Ekonomi Universitas Negeri Yogyakarta dalam Pengajaran Mikro Tahun 2013. Skripsi. Yogyakarta: Fakultas Ekonomi Universitas Negeri Yogyakarta; 2013.

[5] Matti Rautiainen,Marja Mäensivu \&Tiina Nikkola. Becoming Interested during Teacher Education. 2018; https://doi.org/10.1080/02619768.2018.1462329: 418-432.

[6] Pemerintah Republik Indonesia. Pembukaan Undang-Undang Dasar 1945 Alinea Keempat. Tentang Tujuan Bangsa dan Negara Republik Indonesia; 1945.

[7] Pemerintah Republik Indonesia. Undang-Undang Guru dan Dosen (UUGD) No.14 Tahun 2005 Pasal 10 Ayat (1); 2005.

[8] Pemerintah Republik Indonesia. Undang-Undang Republik Indonesia No.20 Tahun 2003. Tentang Sistem Pendidikan Nasional (SisDikNas); 2003.

[9] Raflis Kosasi dan Soetjipto. (2012). Profesi Keguruan. Jakarta: PT. Rineka Cipta.

[10] Slameto. Belajar dan Faktor-faktor yang Mempengaruhinya. Jakarta: PT. Rineka Cipta; 2012. Page 59.

[11] Sugiyono. (2011). Metodologi Penelitian Pendidikan. Bandung: Alfabeta.

[12] Suharsimi Arikunto. (2010). Dasar-dasar Evaluasi Pendidikan. Jakarta: PT. Rineka Cipta.

[13] Suharsimi Arikunto. (2013). Prosedur Penelitian. Jakarta: Bumi Aksara. 